leaf cuttings, and the propagation of ferns from spores are not dealt with.

Common names of American plants and diseases are frequently used. These may be unfamiliar to some English readers ; the legends to Fig. 105 and Fig. 106, to which no further reference in the text is made, read "A live oak top growing on a post oak rootstock" and "Upper part of this tree is live oak, top worked on to a post oak". In both illustrations posts are also shown, so that some confusion may arise, for every reader will not realize that Quercus Virginiana and $Q$. stellata are the plants concerned.

There is a useful chapter dealing with the relation of propagation practice to diseases. This could, with some advantage, be extended to include more pathology, for "Phony peach" conveys little, and the reader is not informed that it may be a virus disease. The grape root louse (Phylloxera) and woolly aphis are included in this chapter on 'diseases'.

There are selected short lists of references, most of which are to American publications, for the several chapters, but the questions at the end of each chapter are of doubtful value. The index would be improved by the inclusion of Latin names. As it briefly surveys a wide field, this will prove a useful book for students desirous of learning the outlines of American nursery methods. M. A. H. T.

\title{
ANIMAL HORMONES
}

\section{Hormones in Invertebrates}

By Prof. Bertil Hanström.

(Monographs on Animal Biology.) Pp. $\mathrm{x}+198+13$ plates. (Oxford : Clarendon Press ; London : Oxford University Press, 1939.) 12s. $6 d$. net.

$\mathrm{O}^{\mathrm{i}}$ F recent years increasing attention has been paid to invertebrates to determine whether they provide evidence of chemical correlation similar to those hormonal reactions that are now recognized as being of tremendous physiological and philosophical importance in the life of man and other vertebrates. Even in 1933 the view was held by some workers that no clearly demonstrated incretory activity in invertebrates, nor any demonstrable influence of vertebrate hormones on invertebrates, had up to that time been found.

Since that time an ocean of endocrinological investigations has been charted, and here Prof. Bertil Hanström has found it useful to present in collated form a more or less complete summary of what is known at present about hormonal reactions in invertebrates. It is now realized that in invertebrates the presence of several incretory organs and many physiological processes cannot be explained without adopting the hypothesis of hormonal action. These investigations show that the previously accepted definition of a hormone as a substance which is secreted into the blood-stream by an endocrine organ, and which exerts a specific effect at another place in the body, is no longer tenable. The absence of blood in many invertebrates and the production of hormonal substances not in incretory glands but in portions of organs the chief function of which is quite other than hormonal, the hypotheses of 'gene hormones', 'growth hormones', 'wound hormones', 'organizers', etc., are evidence that a new hormonal concept should be adduced. In this work Hanström has accepted Köller's hypothesis of considering a hormone as an organic substance which is produced by the organism for its own use, and which has a specific regulatory function within it. As the author suggests, it is clear from the evidence already obtained, which is set out so lucidly in this monograph, that at least some invertebrate hormones may one day be used for important experimental and perhaps pharmacological purposes in vertebrates, including man.

The value of this book to endocrinologists no one would gainsay, but for the non-specialist it is lacking in appeal. In addition to presenting this comprehensive epitome of present-day knowledge, the author might have attempted to introduce a little hypothetical argument when discriminating between apparently diverse statements of fact. For this reason the book, which deals with a fascinating topic, loses a great deal of its attraction for the non-endocrinologist.

The literature index is comprehensive and up to date, but since a considerable portion of the book is given over to the discussion of the influence of vertebrate hormones on invertebrates, it is surprising that the author has omitted any reference to Szent-Györgyi's work on the relations between hormones, vitamins and enzymes. Some original plates make up a volume that must remain as a source-book of information for some time. Incidentally, the book is the first of a new series of monographs on animal biology.

T. H. Hawkins. 